\title{
Transformation of the global oil pricing structure in the conditions of increasing competition of leading players in the oil market
}

\author{
Pavel Katyukha ${ }^{1, *}$ and Angela Mottaeva ${ }^{2}$ \\ ${ }^{1}$ Financial University under the Government of the Russian Federation, 49, Leningradsky prospect, \\ 125993, Moscow, Russia \\ ${ }^{2}$ Moscow State University of Civil Engineering, 26, Yaroslavskoye Shosse, 109377, Moscow, Russia
}

\begin{abstract}
The article proposed by the authors examines the competition between the world's leading producer countries in the context of changing the structure of global oil pricing. The global benchmarks for WTI, Brent and Dubai are the price benchmarks for all oil producing countries in the world, and all changes related to quality, production volumes and supply geography cause structural and institutional changes in the oil market. Crude oil plays an important role in the global economy not only as a commodity, but also as a financial instrument for the redistribution of income between the world's largest financial players.
\end{abstract}

\section{Introduction}

Significant transformation in the structure of pricing in the world oil market in the mid1980s. led to the transition of market participants from traditional long-term agreements at first to spot contracts, which reflected the current market price of oil, to futures contracts, which began to be traded on exchanges. In fact, there has been a diversification of all its mechanisms of functioning with a shift in the vector of development of international trade in oil and oil products from the physical market to the derivatives exchange market on which derivatives are used. This contributed to the identification of a fair market price for oil and provided oil companies with great opportunities to reduce risks and increase profits using financial derivatives [1].

As a result of the transformation of the world oil market, the price of oil is currently set on the world's three largest commodity exchanges: ICE (Intercontinental exchange), NYMEX (New York Mercantile exchange) and DME (Dubai Mercantile Exchange), on which three main international standards are traded. oil (benchmark): futures contracts for North Sea Brent crude, West Texas WTI and Middle East Dubai / Oman [2].

At the moment, Brent and WTI crude oil futures are the most liquid exchange-traded contracts. Physicochemical and logistic differences between Brent and WTI lead to a price difference and form the so-called spread between Brent and WTI, shown in Figure 1. The change in this spread is influenced by factors such as the balance of supply and demand for

\footnotetext{
*Corresponding author: doptaganka@yandex.ru
} 
crude oil in the United States, the level of oil production in the North Sea and geopolitical tensions that could disrupt the supply of crude oil in the world.

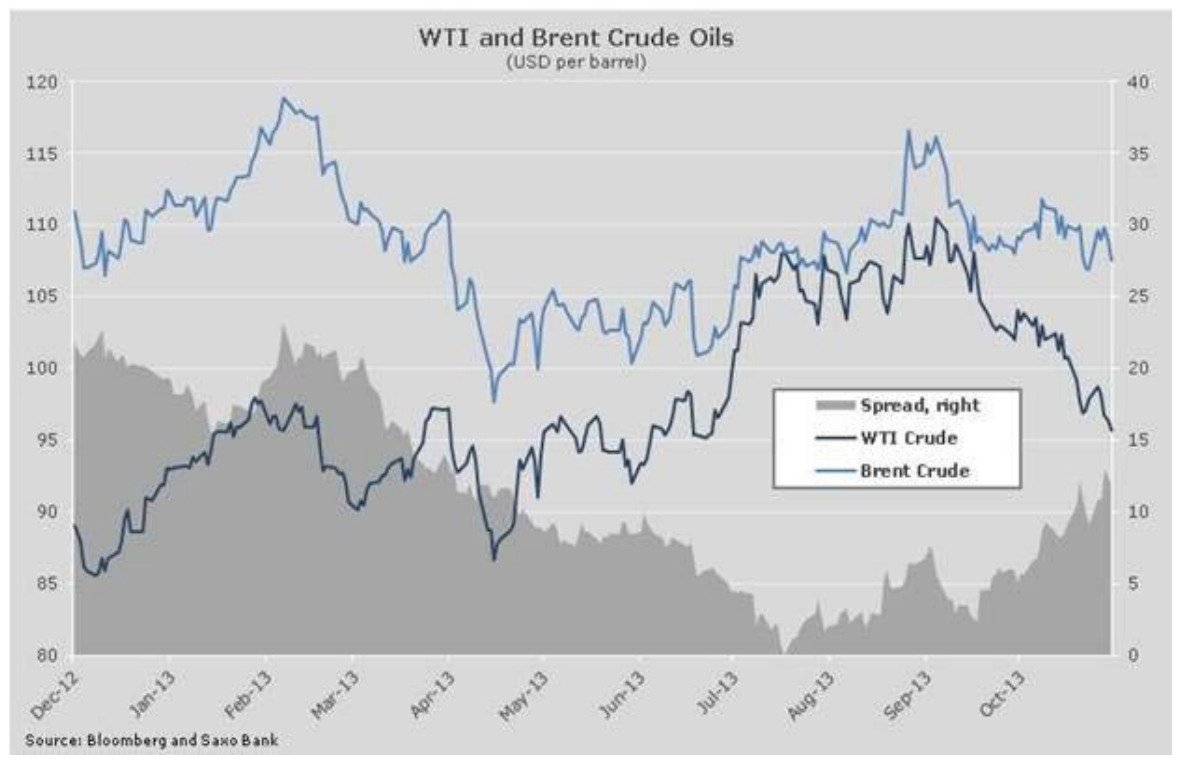

Fig. 1. The chart below shows the spread (price difference) between WTI and Brent. Remark https://bcs-express.ru/novosti-i-analitika/pochemu-rastet-spred-mezhdu-kontraktami-na-neft-brent-iwti.

The shale revolution that began in the United States in the 2010s triggered profound changes in the oil market. Since the beginning of 2015, the United States has been actively increasing oil and according to the BP Energy Statistical review, the production of liquid hydrocarbons, including gas condensate liquids (NGL), has reached a level of over 17 million barrels per day, including NGL. The explosive growth of shale hydrocarbon production in the United States using the latest hydraulic fracturing technologies has made American shale oil a leading indicator of the oil market. This caused structural changes in the global energy market and created the conditions for a regrouping of the world's main oil benchmarks.

\section{Materials and Methods}

In modern economic conditions, characterized by strong turbulence in oil prices and an increase in financial risks, the use of derivative financial instruments in trading operations on the exchange and over-the-counter markets not only united the global financial and commodity markets, but also became a mechanism for the redistribution of speculative capital from the stock and foreign exchange markets to commodity market, and vice versa.

Since 2011, there has been a gradual decline in Brent oil production and now, to maintain liquidity, the Brent crude oil basket includes Brent, Forties, Oseberg, Ekofisk and Troll crude oils. The Brent benchmark, to which more than $70 \%$ of all oil traded in the world is tied, stagnates, loses its connection with the physical oil market and risks losing its status as a marker oil grade (benchmark). BFOE Blend Oil is the base grade for the European and Mediterranean markets and the BFOE Reference Price is used as a basis for determining the price level of other crude grades, taking into account their quality differences and delivery bases. 


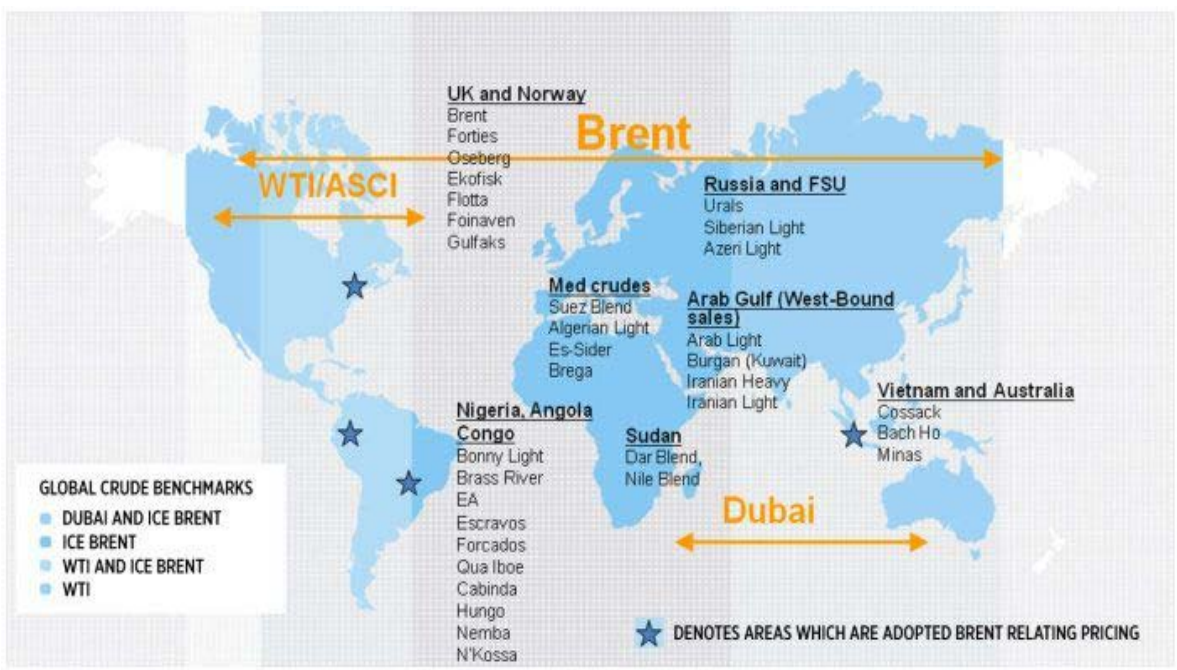

Fig. 2. World benchmarks Brent, WTI, Dubai Remark:

https://www.investopedia.com/articles/investing/102314/understanding-benchmark-oils-brent-blendwti-and-dubai.asp.

The inclusion of new grades did not reinforce the weakening Brent, but further exacerbated the problem of falling production of the Brent oil basket, the volume of which today is significantly lower than a number of the most powerful physical oil flows, including the Russian Urals, Western Canadian WCS (Western Canadian Select) and West Texas WTI. That is, the problem has not been fundamentally resolved, and an aggravation of this problem can be expected in the near future, taking into account the reformatting of WTI, the emergence of the Murban benchmark and Urals, which is gradually gaining liquidity.

The inclusion of various brands in the Brent crude oil basket forced the price agency Platts to introduce quality premiums for three brands (Ekofisk, Oseberg and Troll), which were not previously included in it (quality premia - QPs), and a "de-escalator for high sulfur content" (sulfur -escalator), but in fact a discount for the fourth brand (Forties), which was also not previously included in the basket. Thus, in its evolution, the Brent basket is doing a path that is exactly the opposite of the WTI grade: if the recently increasing West Texas flow does not need the "support" of other brands to maintain production volumes (moreover, since 2019, they are not included in it composition) and at the same time itself disintegrates into separate smaller flows, then the weakening Brent, on the contrary, aggregates more and more brands of the North Sea of excellent quality, which rises new problems for it.

The international pricing agency Platts publishes daily assessments (quotations) of North Sea oil on the spot market for tanker shipments. More than $70 \%$ of all oil traded in the world is traded through a differential to the Brent benchmark. Its calculation is based on the market of forward contracts for oil of the oil basket of the same name. The assessment methodology of the named benchmark is complex and multi-stage, and not always transparent, which is caused by the difficulty of identifying the current price of tanker shipments. The North American price reference WTI is the settlement price for the futures contract of the New York Mercantile Exchange for the oil of the same name [3].

The shale revolution in the United States has become a powerful driver for the entire world oil market and led, first of all, to an increase in the production of hard-to-recover crude oil in the United States (from 2008 to 2018, more than 2 times: from 1.83 billion barrels / 250 million tons to 4, 0 billion barrels / 550 million tons, respectively) and the 
emergence of new sales markets, new bases and centers for fixing prices, which had a great impact on the balance of forces in the structure of world oil pricing. The United States of America, despite the fact that it is the closest allies with Great Britain, got a good chance to oust the North Sea benchmark Brent from the pedestal of the world marker grade of oil, taking into account the fall in volumes and the loss of liquidity, and to form its new, reconstructed WTI price benchmark.

The assumed basis may consist of three potential benchmarks: WTI Cushing - WTI Midland - WTI Houston [4]. The spot (physical) and futures (paper) markets are closely interconnected through the basis and the formation of a new basis depends, first of all, on the development of the market for physical oil exported from the United States, the construction of new terminals and on changes in the transport and logistics infrastructure of the United States. It should be noted that, until recently, the United States was the world's largest producer and consumer of oil in the world.

\section{Pricing locations of selected North American crude oils}

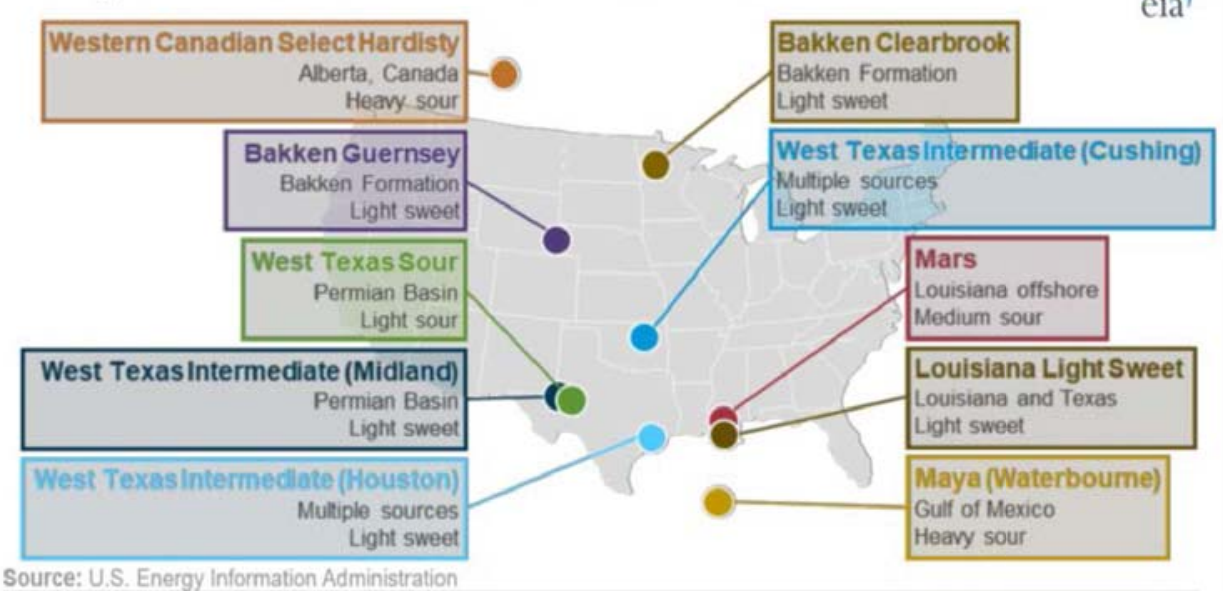

Fig. 3. Benchmarks WTI Cushing - WTI Midland - WTI Houston Remark: US Energy Information Administration.

American grades of crude oil, which until 2019 were allowed to supply under this futures, had to meet a number of characteristics, the most important of which are density (37-42 API, that is, from $816 \mathrm{~kg} / \mathrm{m} 3$ to $840 \mathrm{~kg} / \mathrm{m} 3$ ) and content sulfur (no more than $0.42 \%$ by weight). At the same time, it was forbidden to supply oil mixture, one of the components of which is foreign oil. The underlying asset of the "WTI futures" is oil delivered through the pipeline system, therefore oil in Cushing in a number of cases, purely for technological reasons, is a mixture of different, and not necessarily permitted by the contract, oil brands.

Moreover, the seller could mix different brands both when supplying raw crude oil to the pipeline system and when stored at Cushing. This practice turned out to be so widespread that the product of mixing heavy and ultra-light grades, which did not meet the requirements of the futures, but had the necessary density and sulfur content, received a special name in the USA: "dumbbell crude". Such mixture of crude oils does not allow obtaining a significant amount of middle distillates, but gives a large yield of light distillates and fuel oil, i.e, like a dumbbell, it is "heavy" on both sides and "light" in the middle.

In this content, it is important, that the practice of mixing different grades of crude oil had the most serious effect on the price: even in Cushing, the price fixing point, the abstract NYMEX Crude was most often cheaper than WTI Cushing, which, in turn, noticeably 
(sometimes almost per US dollar per barrel) was inferior to WTI (which itself is usually a mixture), which entered Cushing from fields in West Texas with a guarantee of the absence of "non-Texas" impurities. Thus, the buyer of oil on the "WTI futures" of the New York Mercantile Exchange in practice did not know what kind of oil the seller would provide in case it comes to the delivery of a physical commodity.

\section{Results}

The growing confrontation between the two leading world benchmarks - WTI and Brent gives Russia a unique chance not only to create a Russian benchmark for Urals or ESPO oil and conditions for transparent and independent pricing, but to form a full-fledged derivatives market using a variety of exchange instruments. Currently, prices for Russian oil exported are determined by international price agencies with reference to the North Sea Brent reference grade (benchmark) using a differential formula (discount or premium).

It should be objectively noted that the methods of international price agencies that publish quotations for Urals oil prices are not transparent enough, since they are based on collecting information from the market in various ways, mainly by interviewing international "physical" traders who operate with lots of physical oil. However, the number of transactions in cash oil is too small compared to the volume of the exchange-traded futures market for Brent. Therefore, it is obvious that pricing agencies generally have to use data on the intentions of the parties, rather than data on actually concluded transactions. This approach is not entirely transparent and does not guarantee fair pricing. By the early 2000s. in Russia, all the necessary conditions have ripened for the emergence of a large competitive exchange commodity platform, which will create a transparent exchange mechanism for the formation of wholesale prices for petroleum products.

World practice shows that the exchange, as an infrastructure organization that forms the spot and derivatives markets, allows using modern exchange technologies to successfully solve the problem of increasing the transparency of pricing for oil and oil products by creating mechanisms that stimulate competition among participants in the domestic oil and oil products market. To this purpose, on the initiative of the state, more than ten years ago, exchange trading was launched at the St. Petersburg International Commodity Exchange, which served as a trigger for the formation of an urgent commodity market in Russia and created favorable conditions for reforms in the Russian fuel and energy complex and liberalization of the oil and gas industries in fuel and energy complex of Russia.

The main task of the created exchange was the formation of an organized commodity market and the creation of a reliable mechanism for independent and transparent pricing by developing and introducing new organized trading instruments into exchange trading, including derivative financial instruments such as futures and options. To create a fullfledged exchange infrastructure that meets international exchange trading standards, the Russian exchange must have a full range of appropriate tools and mechanisms [5]. A distinctive feature of the creation of SPIMEX is the fact that the commodity exchange was originally created at the initiative of the state, since the competitive market in some sectors of the Russian economy is still developing and supported by methods of state regulation.

That at this period of time is quite justified in the structure of the fuel and energy complex, since prices for oil products on the domestic market are a rather tense social topic, which cannot but affect the attention of the government. The state perceives the stock exchange as one of the instruments for the development of competition, which is reflected in the National Plan for the Development of Competition. Within the framework of the institutional approach, the state should create equal economic conditions for the development of exchange trade for all existing exchange platforms. In a relatively short period of time, SPIMEX became the largest commodity exchange in Russia, which made it 
possible to make the pricing process on the domestic Russian market more transparent and open.

At the present, SPIMEX is a high-tech, digital platform that unites clearing (settlement and depository company (RDK)), mutual settlements and trading operations in the end-toend electronic information processing mode, which is at the stage of formation of an organized derivatives market, which means a transition to a higher the level of regulation and supervision over the conduct of exchange transactions. This helps traders find the best solutions for all issues related to the sale, purchase, movement, insurance of goods and other related services in the spot, derivatives and OTC markets.

According to stock analysts, the creation of exchange infrastructure similar to those with which the world's largest exchanges, such as NYMEX or ICE, can take more than one or two years. The Russian Federation is one of the largest suppliers of hydrocarbons for export. The flow of Urals oil through the ports of Primorsk, Ust Luga, Novorossiysk exceeds 2 million barrels. per day, through the Druzhba pipeline - more than 1 million barrels. per day. ESPO oil is exported in volumes of about 1 million barrels. per day. It should be noted that the export of Russian oil of Urals and ESPO grades to international markets is twice the supply of oil from the North Sea basket of BFOE, Oman and Dubai combined. Europe is the largest consumer of Russian oil and is historically quite heavily dependent on Russian exports, which account for almost $40 \%$ of all European net imports. In addition, Russia supplies to Europe $85 \%$ of the total volume of imported diesel fuel in this region.

As for the export of Russian oil for the Asia-Pacific region, according to experts, by the end of the decade, oil consumption from China is expected to grow by an average of $2 \%$ per year [7]. In addition to China, the growth of the economies of India, Vietnam, the countries of South America and the Middle East shows a trend towards an increase in demand in the Asia-Pacific region. The stable quality and uniformity of the Russian export mixture, the regularity of supplies and the vast geography of exports create favorable conditions for the formation of our own marker oil grades on the basis of stable export flows of Russian crude oil.

To start trading in futures contracts for Urals oil with the possibility of settlement, it is necessary to develop a market-acceptable methodology for calculating the Urals oil price index. An important characteristic of this technique is its reliance on the prices of export transactions with Russian export oil. The main goal of launching the Urals benchmark project is to create a new pricing mechanism for Urals crude oil through direct market pricing, without reference to other oil benchmarks and actually bridging the gap between prices in the physical and paper oil markets. For this purpose, on November 29, 2016, a futures contract for Russian export oil Urals was launched on the SPIMEX exchange floor on FOB delivery terms to the port of Primorsk. The volume of the contract is 1,000 barrels, the delivery batch is 720 thousand barrels. (100 thousand tons), contract currency - US dollar. Rubles, along with other assets, are accepted as security for the conclusion of exchange transactions.

It should be especially noted that the strategic project of SPIMEX to launch a Russian benchmark for export mixture will allow Russian companies to act not as "price takers" but as "price makers" on the world crude oil market. This is very important in the context of sanctions and a complex geopolitical situation. The creation of a pricing system based on our own reference grade of oil can bring additional revenues from each barrel of exported raw materials, which is in the interests of both exporting companies and the Russian budget. To bring a new benchmark to the international oil market, a number of important conditions must be met: the oil price must be formed transparently and competitively, pricing must be decoupled from other types of foreign market, the market must be legally regulated and have clear rules, contracts must be standardized. 
The Intercontinental Exchange ICE made a statement on November 11, 2019 that the world's leading majors BP, Total and Shell, as well as traders Vitol and South Korea's GS Caltex, Japanese INPEX and JXTG, Petro China, Thailand's PTT have confirmed their agreement partner with the new ICE Futures Abu-Dhabi (IFAD) exchange formed by the Abu Dhabi National Oil Company (ADNOC) in the United Arab Emirates, based in Abu Dhabi next year, with a benchmark based on the Murban oil grade. This means that the new exchange will trade the first deliverable futures contracts for Murban crude oil, which is produced by ADNOC. The partnership of such major global players in the oil market demonstrates the serious intentions of ADNOC and is an important signal for market participants about the claims of the Murban marker to become a new global benchmark.

Launching on a new exchange in Abu Dhabi, Murban's deliverable oil futures will be secured by the physical delivery of crude oil at the Fujairah port in the UAE. Murban is a sweet crude produced by the national company ADNOC. The company produces about 3 million barrels of crude oil per day, of which Murban accounts for about 1.7 million barrels per day. The launch of a new pricing mechanism for Murban crude oil involves the creation of a new price benchmark of crude oil, which will be determined by the market, or rather by market participants and may become a new representative marker grade of oil for oil produced in the Middle East and sold in the Asia-Pacific zone. Pacific region [6].

\section{Conclusions}

As a result of the analysis of the evolution of the pricing structure of the world commodity market, it can be concluded that the competition between the main world oil benchmarks, such as Brent, WTI and Oman / Dubai, is gaining momentum. Leading world powers such as the United States and the United Kingdom actually completed the process of forming market pricing in the $80 \mathrm{~s}$ and $90 \mathrm{~s}$, creating the background for creating global financial centers in the world energy markets through the development of trading in financial instruments (derivatives) on the NYMEX exchanges ( New York Mercantile Stock Exchange) and ICE (Intercontinental exchange). This meant entering the derivatives market, which opens up great opportunities for the main market participants - hedgers and speculators.

Dramatic changes at the global oil market, especially the shale revolution launched by the United States of America several years ago could not help but affect the oil pricing system. The process of formation of new price indicators is actively ongoing, especially in North America, which is primarily caused by a significant increase of oil and gas production in the North American continent as a result of the development of shale oil and gas production. The WTI benchmark holds an increasingly strong position not only in the North and South America, where it has always been traditionally strong, but also in other regions of the world, where before that the Brent marker grade (more precisely, the BFOET price basket) was the starting point for assessing the value of other grades of oil.

Despite the fact that the two largest world commodity exchanges (CME and ICE) and leading price agencies (Argus and S\&P Platts) play a key role in the formation of a new price indicator, much will depend on the prospects for the development of the physical oil market and changes in the transport and logistics infrastructure of the USA fuel and energy complex. This paper is devoted to the transformation of the pricing structure at the global oil market and the strengthening of the role of the West Texas WTI variety.

Russia began creating organized energy trading on the exchange in the early 2000s with a significant delay compared to the United States, Great Britain and Western Europe. In the context of strengthening state regulation in the fuel and energy sector of the Russian economy, it is necessary to more actively develop exchange trading and the derivatives market [5], which will make exchange prices a benchmark for the fuel market. 
The decline in production of crude oil and a significant decrease in the liquidity of trading in crude oil grades that form the North Sea price Brent benchmark, led to a decrease in market participants' confidence in it and to the search for an alternative benchmark grade of oil that would reflect its market value. The need to build a new pricing system for the Russian export mix was one of the reasons for the launch of the Russian Urals benchmark.

The market value of Urals crude oil will be determined not by the world's leading price agencies, but by the main players, which will allow the market to identify a transparent and fair price for Russian oil and determine its direct quotation. In this case, oil becomes a financial asset, which makes it less vulnerable to price manipulation. It is assumed that the launch of a new, Russian benchmark on SPIMEX and the creation of a direct quotation without reference to other markers will be the first step towards a new pricing structure for Russian oil, attract new participants, increase liquidity, recognition and demand for the Russian benchmark and serve as another fulcrum for participants market in determining a fair and transparent oil price.

By the mid-80s, a fundamentally new pricing structure was formed in the global oil market with three exchange centers ICE, NYMEX and DME, where the three main benchmarks Brent, WTI and Dubai / Oman are traded, to which all world grades of oil are tied using a differential. The decline in Brent crude oil production and lower liquidity of this benchmark caused increased competition between existing benchmarks and created the conditions for the appearance of a new benchmark that might change the structure of global oil pricing. The upcoming launch of the Murban marker grade oil on the new Dubai ICE Futures Abu Dhabi exchange, increased confrontation between the Brent and WTI benchmarks and the growing Russian liquidity marker Urals, are leading the world oil market to a price redistribution and transformation of the entire crude oil pricing system.

\section{References}

1. P. Katyukha, Trade in hydrocarbons on the global energy markets (2015) http://elib.gubkin.ru/content/21469

2. https://www.oxfordenergy.org/wpcms/wp-ontent/uploads/2011/03/WPM40AnAnatomyoftheCrudeOilPricingSystem-BassamFattouh-2011.pdf

3. https://www.spglobal.com/platts/en

4. US Energy Information Administration

5. SPIMEX, www/spimex.ru

6. R. El Gamal, R. Bousso, UAE oil benchmark plan confused by Brent comment U-turn, https://www.reuters.com/article/us-emirates-energy-brent/uaeoil-benchmark-planconfused-by-brent-comment-u-turnidUSKBN1XM1Q6

7. China surpassed the United States as the world's largest crude oil importer in 2017. IEA energy news, https://www.eia.gov/todayinenergy/detail.php?id=37821

8. N.Y. Ryazanova, A.V. Sharkova, N.E. Lobzhanidze et al., International Journal of Recent Technology and Engineering 8(1), 2691-2695 (2019) ISSN: 22773878

9. N.S. Khoroshavina, A.V. Sharkova, O.N. Vasilyeva et al., Espacios 39(41), 10 (2018) ISSN: 07981015

10. A. Nassyrova, Z. Yessymkhanova, B. Issayeva et al, Entrepreneurship and Sustainability Issues 8(1), 640-655 (2020) DOI: 10.9770/jesi.2020.8.1(44)

11. G. Nurzhanova, G. Mussirov, S. Niyazbekova et al., Entrepreneurship and Sustainability Issues 8(1), 656-671 (2020) DOI: 10.9770/jesi.2020.8.1(45) 
12. L. Akhmetshina, A. Mottaeva, E3S Web of Conferences 210, 13034 (2020) https://doi.org/10.1051/e3sconf/202021013034

13. N.S. Shcherbakova, Y.A. Nazarova, N.A. Navrotskaia et al., International Journal of Energy Economics and Policy 10(5), 401-408 (2020) DOI: 10.32479/ijeep. 9627

14. T. Kreydenko, M. Chernyaev, E. Grigorieva, A. Korenevskaya, International Journal of Energy Economics and Policy 10(2), 504-511 (2020) DOI: 10.32479/ijeep. 9083

15. N.O. Kurdyukova, M.A. Menshikova, M.D. Dzhamaldinova, EEE International Conference "'Quality Management, Transport and Information Security, Information Technologies"", IT and QM and IS, 246-248 (2020) DOI: 10.1109/ITQMIS51053.2020.9322970

16. A. Rementsov, N. Lebedeva, O. Kirichenko, E3S Web of Conferences 164 (2020) DOI: $10.1051 / \mathrm{e} 3$ sconf/202016410039

17. I.Y.U. Novoselova, I.V. Petrov, A.L. Novoselov, Ugol 8, 88-91 (2020) DOI: 10.18796/0041-5790-2020-8-88-91

18. E.M. Deyanov, N.A. Kharitonova, IOP Conference Series: Materials Science and Engineering 976 (2020) DOI: 10.1088/1757-899X/976/1/012034

19. E. Karieva, L. Akhmetshina, A. Mottaeva, E3S Web of Conferences 217, 07008 (2020) https://doi.org/10.1051/e3sconf/202021707008

20. A. Mottaeva, MATEC Web of Conferences 193, 01022 (2018) doi.org/10.1051/matecconf/201819301022 